\title{
Thoracolumbar Spine Fracture-Dislocation without Neurological Deficit: A Case Report and Review of the Literature
}

\author{
Roger Mulumba Ilunga ${ }^{*}$, Abdoulaye Diop², Mohameth Faye1, Vital Nacoulma1, \\ Nicaise Akodjetin Mahougnon Sodjinou1, Momar Codé Ba ${ }^{3}$ \\ ${ }^{1}$ Department of Neurosurgery, Regional Hospital Center of Thiès, Thiès, Senegal \\ ${ }^{2}$ Department of Neurosurgery, Regional Hospital of Ziguinchor, Ziguinchor, Senegal \\ ${ }^{3}$ Department of Neurosurgery, National Teaching Hospital of Fann, Dakar, Senegal \\ Email: *rogermulumba2004@gmail.com
}

How to cite this paper: Ilunga, R.M., Diop, A., Faye, M., Nacoulma, V., Sodjinou, N.A.M. and Ba, M.C. (2021) Thoracolumbar Spine Fracture-Dislocation without Neurological Deficit: A Case Report and Review of the Literature. Open Journal of Orthopedics, 11, 153-163.

https://doi.org/10.4236/ojo.2021.115015

Received: March 30, 2021

Accepted: May 10, 2021

Published: May 13, 2021

Copyright $\odot 2021$ by author(s) and Scientific Research Publishing Inc. This work is licensed under the Creative Commons Attribution International License (CC BY 4.0).

http://creativecommons.org/licenses/by/4.0/

\begin{abstract}
Background: Thoracolumbar spine fracture-dislocations are very unstable and usually secondary to high energy trauma. Due to disruption of the entire vertebrae columns, the absence of neurological deficit is exceptional. Aim: The purpose of this work is to report our experience in the management of this entity in a context of limited resources and to make a review of the literature. Case presentation: A 30-year-old man was admitted with a severe low back pain after a traffic accident. Neurological functions were intact after examination. Radiological assessments revealed a complete L3-L4 fracture-dislocation. The patient underwent an open posterior reduction and internal long segment fixation. The post-operative was marked by a surgical site infection treated with surgical debridement and targeted antibiotic therapy. The neurological functions were preserved. Conclusion: Fracture-dislocations of the thoracolumbar spine are caused by high energy trauma and are remarkably unstable lesions. When they are associated with intact neurorological functions, reduction and stabilization of these fractures are a challenge.
\end{abstract}

\section{Keywords}

Spine Fracture-Dislocation, Thoracolumbar Spine, Spine Surgery, Trauma

\section{Introduction}

Fracture-dislocation of the thoracic and lumbar vertebral column comprised 3\% of the injuries related to the vertebral column [1]. Common injuries resulting in fractures of the thoracolumbar spine include fall from a height, motor vehicle 
and pedestrian accidents, and penetrating trauma (gunshot wounds and stabbings) [2] [3]. Fracture-dislocation is defined as failure of all three columns of the spine with gross displacement [4] [5] [6]. There is a typically complete disruption of the stabilizing ligaments, facet joint capsules and the paraspinal musculature resulting in the translation of the spinal column and the transfer of shearing forces leading to disruption of the spinal cord. Considering the significant violence necessary to produce fracture-dislocations, these injuries are often associated with major neural deficit and since the spinal column is grossly unstable because of the column disruption, there are significant risks of further instability and neurological deficit during transfer, positioning on the operating table, and surgical intervention. The management is usually straightforward, the injuries are managed surgically and surgical fixation enables early mobilization and rehabilitation. Preservation of neurological function following complete fracture-dislocation is a quite rare entity. There are a few neurologically intact cases in the literature [7]-[23] (Table 1) and none has been reported from Senegal. Here, we report our experience in the management of this entity in a context of limited resources and we make a review of the literature.

\section{Case Presentation}

A 30-year-old man was admitted with severe low back pain after a traffic accident. He was a passenger on a motorcycle that collided with a truck. On examination, his vital signs were normal. His Glasgow coma scale score was $15 / 15$, the sensation and muscle strenght were preserved, no pathological reflex was noted, bladder and bowel functions were normal. He had a severe tenderness on his lower back and pain when moving the left knee.

The X-ray and the Computed tomography (CT) of the lumbar spine revealed a rotational-dislocation of the $\mathrm{L} 3$ to $\mathrm{L} 4$ vertebrae with fractured bilateral inferior facets of L3 and corporeal split fracture and compression of L3 (Figure 1). The $\mathrm{X}$-ray of the left knee was normal. The laboratory tests prior to surgery were normal (Table 2).

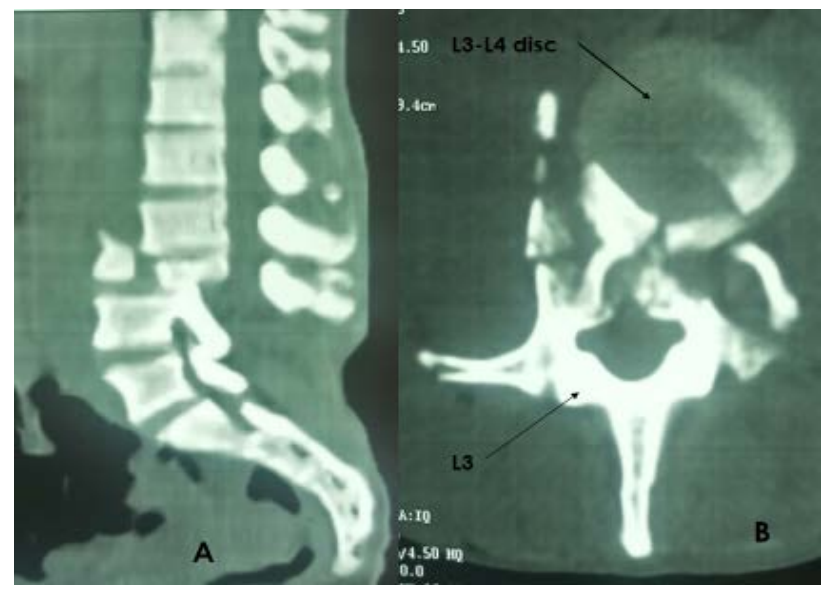

Figure 1. Sagittal (A) and axial (B) computed tomography of the complete fracture-dislocation of the L3 and L4 vertebrae. 
Table 1. Summary of thoracolumbar fracture-dislocations with neural sparing.

\begin{tabular}{|c|c|c|c|c|c|c|c|}
\hline References & Age/Sex & Location & Fractured facet/pedicle & Aetiology & $\begin{array}{l}\text { Time of } \\
\text { surgery }\end{array}$ & Surgery & Outcome \\
\hline $\begin{array}{l}\text { Weber } \\
\text { et al. [7] }\end{array}$ & $19, \mathrm{M}$ & T6-T7 & $\begin{array}{l}\text { Right tranverse pedicle } \\
\text { process of } \mathrm{T} 4-5 \text { with } \\
\text { fracture of body and } \\
\text { pedicle } \mathrm{T} 7-10\end{array}$ & $\begin{array}{l}\text { Motor cycle } \\
\text { accident }\end{array}$ & 6 Days & $\begin{array}{l}\text { Reduced anteriorly using } \\
\text { Harrington distraction rod and } \\
\text { fixed with an AO broad plate } \\
\text { then augmented posteriorly with } \\
\text { segmental spinal instrumentation }\end{array}$ & Good \\
\hline $\begin{array}{l}\text { Korovessis } \\
\text { et al. [8] }\end{array}$ & $24, \mathrm{M}$ & T5-6 & & $\begin{array}{l}\text { Motor cycle } \\
\text { accident }\end{array}$ & 6 Week & $\begin{array}{l}\text { Two Luque L-rods with } \\
\text { sublaminar wires from T4-11 } \\
\text { Good }\end{array}$ & Good \\
\hline $\begin{array}{l}\text { Akay } \\
\text { et al. [9] }\end{array}$ & $21, \mathrm{M}$ & T12-L1 & $\begin{array}{l}\text { Right inferior facet of } \mathrm{T} 12 \\
\text { and left superior facet and } \\
\text { pedicle of L1 }\end{array}$ & Car accident & NA & $\begin{array}{l}\text { T12-L1 Posterior screws, rod } \\
\text { fixation (T11, T12, L2, L3) and } \\
\text { posterolateralfusion (T12-L1) }\end{array}$ & Good \\
\hline $\begin{array}{l}\text { Kiymaz } \\
\text { et al. [10] }\end{array}$ & $35, \mathrm{~F}$ & L2-L3 & & Car accident & & $\begin{array}{l}\text { Reduction, T12L1-L2L3 } \\
\text { transpedicular screws }\end{array}$ & \\
\hline $\begin{array}{l}\text { Phadnis } \\
\text { et al. [11] }\end{array}$ & $21, \mathrm{M}$ & L1-L2 & $\begin{array}{l}\text { Right pedicle of } \mathrm{L} 1 \text { and left } \\
\text { pedicle of L2 }\end{array}$ & $\begin{array}{l}\text { Road traffic } \\
\text { accident }\end{array}$ & 48 Hours & $\begin{array}{l}\text { Posterior screws, rod fixation (T12, } \\
\text { L1, L3, L4) and interbody fusion } \\
\text { (L1-L2) }\end{array}$ & Good \\
\hline $\begin{array}{l}\text { Hsieh } \\
\text { et al. [12] }\end{array}$ & $50, \mathrm{M}$ & T12-L1 & $\begin{array}{l}\text { Right pedicle of } \mathrm{L} 1 \text { and } \\
\text { bilateral facet joints } \\
\text { between } \mathrm{T} 12 \text { and } \mathrm{L} 1\end{array}$ & Fall from bicycle & 3 Hours & $\begin{array}{l}\text { Posterior screws, rod fixation } \\
(\mathrm{T} 10, \mathrm{~T} 11, \mathrm{~L} 2, \mathrm{~L} 3) \text { and } \\
\text { posterolateral fusion (T12-L1) }\end{array}$ & Good \\
\hline $\begin{array}{l}\text { Hidalgo- } \\
\text { Ovejero } \\
\text { et al. }[13]\end{array}$ & $40, \mathrm{~F}$ & L3-L4 & & Airplane accident & 72 Hours & $\begin{array}{l}\text { Laminectomy, facetectomy, } \\
\text { corporectomy, reduction, fixation } \\
\text { and fusion }\end{array}$ & \\
\hline $\begin{array}{l}\text { Solera } \\
\text { et al. }[14]\end{array}$ & $51, \mathrm{M}$ & T8-T9 & & Fall from $10 \mathrm{~m}$ & $<6$ Hours & $\begin{array}{l}\text { Open reduction and posterior } \\
\text { instrumentation }\end{array}$ & Good \\
\hline $\begin{array}{l}\text { Solera } \\
\text { et al. }[14]\end{array}$ & $29, \mathrm{M}$ & $\mathrm{T} 10$ & & $\begin{array}{l}\text { Road traffic } \\
\text { accident }\end{array}$ & & $\begin{array}{l}\text { Open reduction and fixation with } \\
\text { pedicle screws at } \mathrm{T} 8-\mathrm{T} 12\end{array}$ & Good \\
\hline $\begin{array}{l}\text { Sugiura } \\
\text { et al. [15] }\end{array}$ & $18, \mathrm{M}$ & T12-L1 & & & & $\begin{array}{l}\text { Anterior only fusion } \\
\text { instrumentation }\end{array}$ & Good \\
\hline $\begin{array}{l}\text { Zeng } \\
\text { et al. [16] }\end{array}$ & $38, \mathrm{M}$ & L1-L2 & $\begin{array}{l}\text { Bilateral pedicles of } \mathrm{L} 2 \\
\text { and bilateral facet joints } \\
\text { between } \mathrm{L} 1 \text { and } \mathrm{L} 2\end{array}$ & $\begin{array}{l}100 \mathrm{~kg} \text { rebar } \\
\text { fell on his back }\end{array}$ & 72 Hours & $\begin{array}{l}\text { Laminectomy }(\mathrm{L} 1, \mathrm{~L} 2) \text {, posterior } \\
\text { screws, rod fixation and } \\
\text { posterolateral fusion } \\
(\mathrm{T} 12, \mathrm{~L} 1, \mathrm{~L} 2, \mathrm{~L} 3, \mathrm{~L} 4)\end{array}$ & Good \\
\hline $\begin{array}{l}\text { Evans } \\
\text { et al. [17] }\end{array}$ & $44, \mathrm{M}$ & T12-L1 & NA & $\begin{array}{l}\text { Gym accident, } 200 \\
\mathrm{~kg} \\
\text { bar fell on his } \\
\text { lower back }\end{array}$ & $<24$ Hours & $\begin{array}{l}\text { Open reduction and internal } \\
\text { fixation of the vertebral bodies } \\
\text { (T12-L1) }\end{array}$ & Good \\
\hline $\begin{array}{l}\text { Enishi } \\
\text { et al. [18] }\end{array}$ & $35, \mathrm{~F}$ & L1-L2 & No & $\begin{array}{l}\text { Motor vehicle } \\
\text { accident }\end{array}$ & 5 days & $\begin{array}{l}\text { Laminectomy followed by subtotal } \\
\text { corpectomy (L2) and anterior } \\
\text { fixation (L1-L3) }\end{array}$ & Good \\
\hline $\begin{array}{l}\text { Rahimizadh } \\
\text { et al. [19] }\end{array}$ & $19, \mathrm{~F}$ & L1-L2 & No & Fall from a height & 14 Days & $\begin{array}{l}\text { Posterior screws, rod fixation } \\
(\mathrm{T} 11, \mathrm{~T} 12, \mathrm{~L} 1, \mathrm{~L} 3, \mathrm{~L} 4, \mathrm{~L} 5) \text { and } \\
\text { anterior corpectomy (L2) }\end{array}$ & Good \\
\hline $\begin{array}{l}\text { Zhang } \\
\text { et al. [20] }\end{array}$ & $35, \mathrm{~F}$ & T6-T7 & $\begin{array}{l}\text { Left pedicle of T4; spinous } \\
\text { process, vertebral laminae, } \\
\text { and bilateral pedicles of T5 } \\
\text { and T6; spinous process of } \\
\text { T7 and both pedicles of T8 }\end{array}$ & $\begin{array}{l}\text { A } 80-\mathrm{Kg} \text { heavy giant } \\
\text { rubber tire with } \\
\text { metal whell hub fell } \\
\text { on her back from } \\
\text { about } 10 \mathrm{~m} \text { high }\end{array}$ & 6 days & $\begin{array}{l}\text { Laminectomy T5-T8, } \\
\text { transpedicular screws } \\
(\mathrm{T} 3, \mathrm{~T} 4, \mathrm{~T} 5, \mathrm{~T} 8, \mathrm{~T} 9) \text { and rods } \\
\text { fixation, posterolateral fusion } \\
\text { T3-T9 }\end{array}$ & Good \\
\hline
\end{tabular}




\section{Continued}

\begin{tabular}{|c|c|c|c|c|c|c|c|}
\hline $\begin{array}{l}\text { Junfeng } \\
\text { et al. [21] }\end{array}$ & $38, \mathrm{M}$ & L1-L2 & $\begin{array}{l}\text { Bilateral pedicles of } \mathrm{L} 2 \\
\text { and bilateral facet joints } \\
\text { between } \mathrm{L} 1 \text { and } \mathrm{L} 2\end{array}$ & $\begin{array}{l}100 \mathrm{~kg} \text { rebar fell on } \\
\text { his back and he fell } \\
\text { from a scaffold of } 3 \\
\mathrm{~m} \text { in height }\end{array}$ & 72 Hours & $\begin{array}{l}\text { Laminectomy (L1, L2), posterior } \\
\text { screws, rod fixation and } \\
\text { posterolateral fusion } \\
(\mathrm{T} 12, \mathrm{~L} 1, \mathrm{~L} 2, \mathrm{~L} 3, \mathrm{~L} 4)\end{array}$ & Good \\
\hline $\begin{array}{l}\text { Kumar } \\
\text { et al. [22] }\end{array}$ & $25, \mathrm{~F}$ & T10-T11 & $\begin{array}{l}\text { Posterior elements of } \mathrm{T} 10 \\
\text { involving the bilateral } \\
\text { lamina, with pedicle }\end{array}$ & Road traffic accident & 5 Days & $\begin{array}{l}\text { Laminectomy }(\mathrm{T} 10, \mathrm{~T} 11), \\
\text { posterior screws, rod fixation and } \\
\text { posterolateral fusion }\end{array}$ & Good \\
\hline $\begin{array}{l}\text { Kumar } \\
\text { et al. [22] }\end{array}$ & $26, \mathrm{~F}$ & T12-L1 & $\begin{array}{l}\text { fracture dislocation at the } \\
\text { T12-L1 managed with } \\
\text { short fixation followed } \\
\text { by implant failure and } \\
\text { removal }\end{array}$ & $\begin{array}{l}\text { Road traffic a } \\
\text { accident }\end{array}$ & & $\begin{array}{l}\text { Laminectomy of T12-L1 levels, } \\
\text { factectomy and discectomy T12-L1, } \\
\text { deformity correction followed by } \\
9 \times 25 \mathrm{~mm} \text { bullet cage and bilateral } \\
\text { transpedicular screws, rod fixation. }\end{array}$ & Good \\
\hline $\begin{array}{l}\mathrm{Xu} \mathrm{F} \\
\text { et al. [23] }\end{array}$ & $42, \mathrm{M}$ & L3-L4 & $\begin{array}{l}\text { Pedicles L4 to S1, } \\
\text { spondyloptosis }\end{array}$ & Fall & 7 Days & $\begin{array}{l}\text { Reduction, intervertebral fusion, } \\
\text { internal fixation }\end{array}$ & \\
\hline $\begin{array}{l}\text { Present } \\
\text { case }\end{array}$ & $30, \mathrm{M}$ & L3-L4 & $\begin{array}{l}\text { Bilateral inferior facets } \\
\text { of L3 }\end{array}$ & Road traffic accident & 7 Days & $\begin{array}{l}\text { Laminectomy of L4, } \\
\text { Lamino-arthrectomy of L3, } \\
\text { Transpedicular screws } \\
\text { (L1, L2, L4, L5) and rods fixation }\end{array}$ & Good \\
\hline
\end{tabular}

M: Male F: Female NA: Not available.

Table 2. Laboratory investigations of the case before surgery.

\begin{tabular}{cc}
\hline Parameters & Results \\
\hline White blood cells $(\mathrm{WBC})$ count, $\times 10^{9} / \mathrm{L}$ & $9.35(4.0-10)$ \\
Red blood cells count, $\times 10^{9} / \mathrm{L}$ & $4.45(4.0-5.5)$ \\
Hemoglobin $/ \mathrm{dL}$ & $12.8(12-16)$ \\
Hematocrit $\%$ & $37.5(39-45)$ \\
Platlets count, $\times 10^{9} / \mathrm{L}$ & $245(150-450$ \\
Prothrombin Time (PT) \% & $86.1(70-100)$ \\
International Normalized Ratio (INR) & 1.12 \\
Blood Group and Rhesus & $\mathrm{A}^{+}$ \\
\hline
\end{tabular}

Surgery was performed 7 days after initial injury. The patient was placed in the prone position under general anesthesia on a non X-ray transparent operating table. Sensory evoked potential responses (SSEP) monitoring was not available. A posterior middle incision was made from T12 to L5 revealing a contusion of paravertebral muscles, rupture of the supraspinous and interspinous ligaments at the L3-L4 level and a fracture of both inferior facets of L3. Laminectomy of L3-L4 and inferior facetectomy of L3 were performed. Bilateral transpedicular $45 \mathrm{~mm}$ screws were inserted in the L1, L2, L4 and L5 vertebrae under intraoperative lateral fluoroscopic imaging. The realignment was made with reduction forceps applied on spinous process of L2 and L4; stabilization was achieved with rods and tightened nuts. Posterolateral grafting was performed with autologous bone harvest from the resected posterior arc. The operating site was then irrigated with $0.9 \%$ saline solution and a drain was placed and secured with a suture before wound closure.

On day 1 after surgery, neurological functions were intact. On day 2, the drain 
was removed and the lumbar spine control x-ray showed good spinal alignment (Figure 2). The patient was allowed to walk with a brace on day 3 after surgery (Figure 3). The patient presented, 6 days after surgery, fever, wound dehiscence and purulent drainage from the wound. An open surgical debridement was done the same day and the exploration of the wound established a superficial infection. Cultures of the surgical site were obtained and broad spectrum antibiotics were initiated and then the antibiotics were tailored to culture's results 4 days after (Table 3 ). The evolution was satisfactory and the patient was discharged on day 29 after surgery with preserved neurological functions. The brace was removed 3 months later and the patient remained neurologically asymptomatic at 2 years follow-up. Due to his financial limitation neither a CT nor an X-ray could be done to assess the bony fusion.

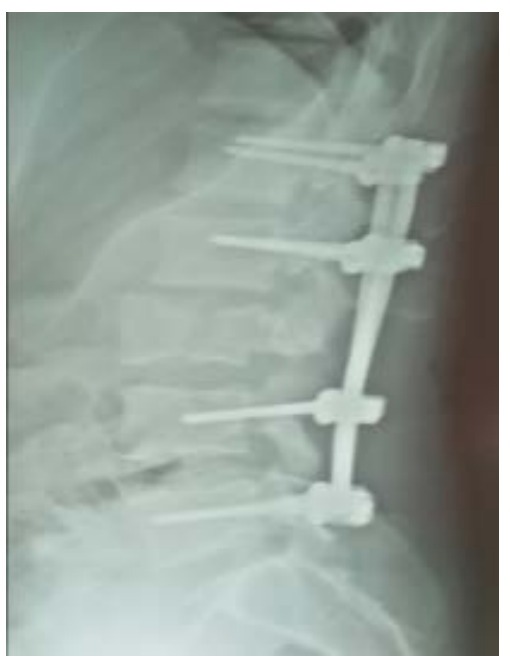

Figure 2. Postoperative lateral X-rays showing good realignment of the the lumbar spine.

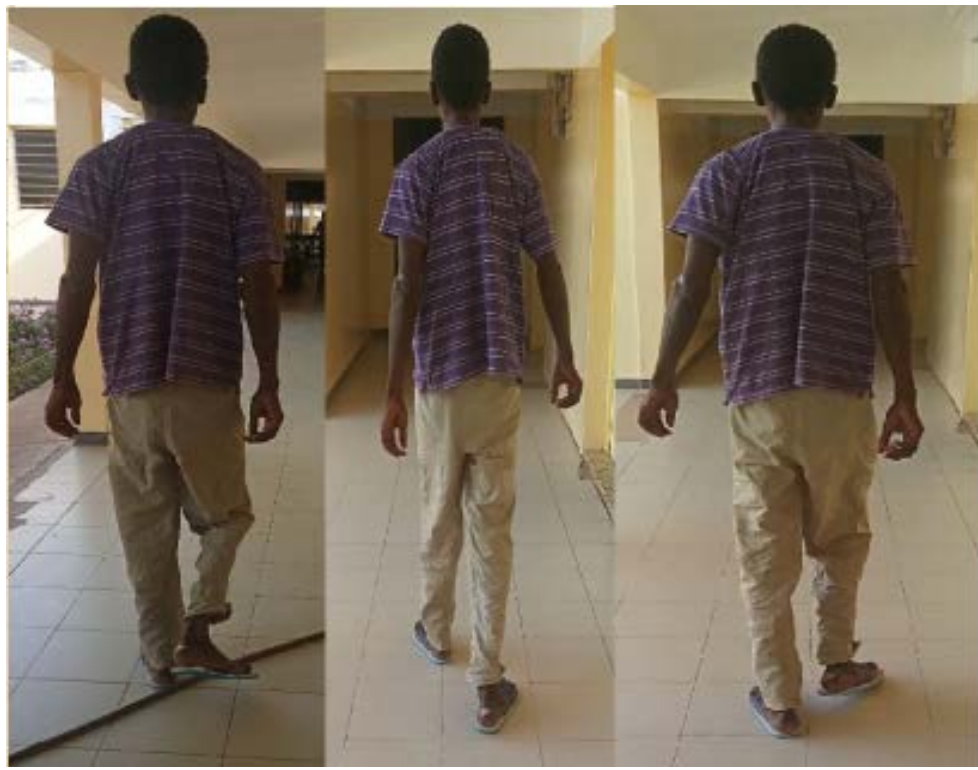

Figure 3. The patient walking with a brace on day 3 after surgery. 
Table 3. Laboratory investigations for infection and antibiotics protocols.

\begin{tabular}{|c|c|}
\hline Laboratory investigations & \\
\hline WBC count, $\times 10^{9} / \mathrm{L}$ & $23.67(4.0-10)$ \\
\hline C- Reactive Protein (CRP) mg/dL & 236.2 \\
\hline Cultures & Streptococcus spp \\
\hline \multicolumn{2}{|c|}{ Antimicrobial treatments for the infection } \\
\hline Prior to culture's results & $\begin{array}{l}\text { Intravenous (IV) treatment Ciprofloxacin } 2 \times 200 \\
\mathrm{mg}+\text { Metronidazole } 3 \times 500 \mathrm{mg} \text { for } 4 \text { days }\end{array}$ \\
\hline After culture's results & $\begin{array}{l}\text { Ceftriaxone } 2 \times 2 \mathrm{~g} \text { for } 2 \text { weeks }+ \text { Gentamycin } \\
1 \times 240 \mathrm{mg} \text { for } 5 \text { days. This IV treatment was } \\
\text { followed by a } 3 \text { weeks oral treatment with } \\
\text { Amoxicillin/Clavulanic Acid } 3 \times 1.2 \mathrm{~g}\end{array}$ \\
\hline
\end{tabular}

\section{Discussion}

Fracture-dislocation of the thoracolumbar spine is rare. It requires a very high energy trauma and a direct application to the spine, most often, of shearing forces [24]. This injury mechanism shows the importance of displacement and the highly unstable nature of this injury due to the rupture of the three columns. The neurological prognosis is usually severe resulting in permanent paraplegia. Neurological trauma is very often related to the rupture of nerve structures during the translational displacement of the spine or the sudden and extreme tension of these structures without rupture [20].

Rare cases of fracture-dislocations without neurological disorder have however been described. The crucial element in preserving neurological functions in these cases is spontaneous decompression of the spinal canal [20] [25]. Thus, the fracture of the pedicles or the facet joints, at the involved vertebrae, contributes to significantly widen the vertebral canal, protecting its contents [7] [9] [11] [12] [16] [20] [21] [22] [23]. Junfeng et al. [21] reported a case of complete fracture-dislocation of the L1 to L2 vertebrae with a normal neurological examination. He claimed that the mechanism of neural preservation was spontaneous decompression from fractured bilateral pedicles of L2 and bilateral facet joints between L1 and L2. Rahimizadeh et al. [19] also reported such a case and speculated about the possibility of the existence of a preservation mechanism for the functional integrity of the cord despite gross spinal fracture-dislocation. They reproduced the injury on a plastic model and simulated a corresponding model using 3D Slicer software with the help of CT data, along with a detailed description of the pathomechanism of neurologic sparing. It was interpreted that a mechanism other than saving fractures could have protected the cord in spite of the near-complete dislocation. They demonstrated that violent hyperflexion in combination with shearing rotational stress affected the intervertebral L1-L2 disc. Continued shearing forces, accompanied by rotational forces with the spinal cord as a hinge, led to the corresponding facet joints getting engaged and locked, with the spinal canal still remaining aligned. Tetsuya et al. [26] presented two 
cases with significant fracture-dislocation of the thoracic or lumbar spine without neurologic deficits. In each case, certain factors were considered crucial to neuropreservation. In the first case, bilateral pedicle fractures at the involved levels preserved the relationship between the spinal canal and the posterior elements; in the second case, rotational displacement and collapse of the broken vertebrae decompressed the dura and widened the spinal canal. In our case, we had rotational dislocation-fractures with fractured bilateral inferior facets of L3 joints between L3-L4 and a corporeal split fracture and compression of the L3 vertebrae. Furthermore, in fracture-dislocations of the lumbar region, two anatomical facts can help preserve neurological damage in patients, when compared with trauma in the cervical or thoracic region. Firstly, the spinal cord in adults extends only to the lower edge of the first lumbar vertebra, and secondly, the large vertebral space in this region gives ample space for the roots of the cauda equine. As a result, the nerve injury may be minimal, because the nerve roots in this region are accommodated in a larger area, with less content [27].

Due to high energy trauma, fracture-dislocations of the thoracolumbar spine may be associated with various organ injuries which can delay the diagnosis [19]. Having an accurate and early diagnosis is critically important before any improper maneuver can be applied to patients. Some authors have recommended a spinal computed tomography for patients involved in severe high velocity trauma [9] [12].

Surgery is recommended for fracture-dislocations of the thoracolumbar spine and should be performed at the earliest possible opportunity for neurologic protection [6] [21] [28] [29] [30]. The physical condition of the patient, as well as the potential existence of associated lesions, should always be taken into account before attempting the procedure. It is also important for patients to be stabilized before surgery, and for the right personnel to be available at the time of decompression and reduction of these injuries [13]. The objectives of the surgery are reduction of dislocated vertebrae, decompression of nerve structures, spinal stabilization and an early mobilization and rehabilitation [28] [31]. In our case, through a posterior approach, we performed laminectomy and facetectomy at the involved level of compression; a long transpedicular fixation and posterolateral fusion were performed. The optimal surgical approach for decompression and stabilization is controversial. A posterior approach with long instrumentation ( 2 levels above and 2 levels below) is recommended due to the severe instability of the injured spine. In addition, short bony fusion, that is, posterolateral or interbody fusion, should be applied [9] [11] [12] [29]. Junfeng $Z$ et al. [21], for a complete fracture-dislocation in 38-year-old patient, performed a long instrumentation and long posterolateral fusion for fixation to avoid implant failure. He obtained a solid fusion and a satisfactory outcome at the 23-month follow-up.

Anterior approach for fracture-dislocation injury may not be applicable as the reduction of the fracture through an anterior approach alone is very difficult and in some cases impossible. Realignment and fixation are best accomplished 
through a posterior approach with reduction, multilevel instrumentation and fusion [32]. Circumferential anterior and posterior fusion often plays a role in these severely injured cases. Xia et al. [33] advocated this combined surgery for thoracolumbar fracture-dislocations and he conclued that simultaneously combined anterior and posterior surgery was a reliable method that can achieve a sufficient decompression, reduction and reconstruction. Xiao-Bin $\mathrm{W}$ et al. [32] performed a posterior TLIF approach with a single stage pedicle screw fixation and interbody bone graft to achieve reduction, decompression and reconstruction for the treatment of thoracic and lumbar fracture-dislocations. He claimed that it is a safe procedure because working zone can be acquired without retraction on the spinal cord. He believed that the advantages of one stage posterior approach are multiples: less invasive, anatomical reduction and kyphotic correction, sufficient neural decompression, anterior column fusion and long term correction maintenance.

Reduction, whether open or closed, should be performed with great care and with the aid of pre-operative and post-operative imagings. Hidalgo-Ovejero AM et al. [13] applied a halo-bifemoral treatment, on a patient with a L3-L4 dislocation without neurological lesions, before surgery. This system is used for the reduction of spine deformities and fracture-dislocations [34] [35] [36]. However, it has been less used since the recent developpment of powerfull new surgical techniques and instrumentations. Meticulous care should be taken during the surgical reduction of the injuries to avoid iatrogenic vascular and neurological lesions. Sapan Kumar et al. [37] have summerised the published literature papers on the surgical management of thoracolumbar fracture-dislocations and described the reduction maneuvers used in detail. In our case, the realignment was made with reduction forceps applied on spinous process of L2 and L4. This technique is among the five different techniques described by the AO Spine group. Advantage of this technique is the relative simplicity of the maneuvers. As only spinous processes are manually distracted, theoretically lesser risk of neurological insult is there. Disadvantages are higher risk of cut-out of the towel clips through spinous processes, particularly in osteoporosis cases, and hence failure to achieve reduction [37]. Rishi MK et al. [38] insisted on critical steps to ensure safe surgical reduction of the spine: Unilateral exposure and temporary fixation, use of high-speed burr and drill to create screw track, avoid torque forces while inserting the screws, perform a laminectomy before reducing the dislocation, use of gentle reduction maneuvers with persuaders and rod rotation under direct visualization of the spinal cord. Overall, experience and expertise of the operating surgeon is also important, as unintended neural injury can happen if appropriate care is not taken.

\section{Conclusion}

Fracture-dislocations of the thoracolumbar spine are caused by high energy trauma and are remarkably unstable lesions. When they are associated with in- 
tact neurorological functions, reduction and stabilization of these fractures are a challenge for spine surgeons, especially in a context of limited resources. In view of our results and the literature, early diagnosis and surgical treatment ensure a good prognosis.

\section{Informed Consent}

Informed consent was obtained from the patient for publication of this manuscript and any accompanying images.

\section{Conflicts of Interest}

The authors declare no conflicts of interest regarding the publication of this paper.

\section{References}

[1] Mohammadi, H.R. and Zandi, S. (2013) Complete Traumatic Fracture-Dislocation L3-L4 of the Lumbar Spine. Pakistan Journal of Medical Sciences, 29, 1283-1284. https://doi.org/10.12669/pjms.295.3783

[2] Xiong, W., Li, F., Zhang, F., Huo, X. and Chen, A. (2013) Single-Stage Operation for Traumatic Thoracolumbar Fractures with Severe Dislocation via a Posterior Approach Alone: A Case Series. Turkish Neurosurgery, 23, 170-178. https://doi.org/10.5137/1019-5149.JTN.5782-12.2

[3] Bernstein, M.P., Mirvis, S.E. and Shanmuganathan, K. (2006) Chance-Type Fractures of the Thoracolumbar Spine: Imaging Analysis in 53 Patients. American Journal of Roentgenology, 187, 859-868. https://doi.org/10.2214/AJR.05.0145

[4] Vaccaro, A.R., Zeiller, S.C., Hulbert, R.J., Anderson, P.A., Harris, M., Hedlund, R., et al. (2005) The Thoracolumbar Injury Severity Score: A Proposed Treatment Algorithm. Clinical Spine Surgery, 18, 209-215.

[5] De Lucas, J.C., Alvarez, L., Abril, J.C. and Calvo, E. (1994) Fracture-Dislocation of the Thoracic Spine without Neurological Lesion. Injury, 25, 105-107.

https://doi.org/10.1016/0020-1383(94)90112-0

[6] Magerl, F., Aebi, M., Gertzbein, S.D., Harms, J. and Nazarian, S. (1994) A Comprehensive Classification of Thoracic and Lumbar Injuries. The Journal of Trauma and Acute Care Surgery, 3, 184-201. https://doi.org/10.1007/BF02221591

[7] Weber, S.C. and Sutherland, G.H. (1986) An Unusual Rotational Fracture Dislocation of the Thoracic Spine without Neurologic Sequelae Internally Fixed with a Combined Anterior and Posterior Approach. The Journal of Trauma and Acute Care Surgery, 26, 474-479. https://doi.org/10.1097/00005373-198605000-00012

[8] Korovessis, P., Sidiropoulos, P. and Dimas, A. (1994) Complete Fracture Dislocation of the Thoracic Spine without Neurologic Deficit: Case Report. The Journal of Trauma and Acute Care Surgery, 36, 122-124. https://doi.org/10.1097/00005373-199401000-00022

[9] Akay, K.M., Baysefer, A., Kayali, H., et al. (2003) Fracture and Lateral Dislocation of the T12-L1 Vertebrae without Neurological Deficit-Case Report. Neurologia Medico-Chirurgica, 43, 267-270. https://doi.org/10.2176/nmc.43.267

[10] Kiymaz, N., Yilmaz, N. and Mumcu, C. (2005) Traumatic Lumbar Fracture-Dislocation Related to Spina Bifida Occulta: Case Report. Hiroshima Journal of Medical Sciences, 54, 57-59. 
[11] Phadnis, A.S., Tan, C.J., Raman, A.S., et al. (2006) Fracture and Complete Dislocation of the Spine with a Normal Motor Neurology. Injury Extra, 37, 479-483. https://doi.org/10.1016/j.injury.2006.06.112

[12] Hsieh, C.T., Chen, G.J., Wu, C.C., et al. (2008) Complete Fracture-Dislocation of the Thoracolumbar Spine without Paraplegia. American Journal of Emergency Medicine, 26, 633.e5-7. https://doi.org/10.1016/j.ajem.2007.09.023

[13] Hidalgo-Ovejero, A.M., Garcia-Mata, S., Martinez-Lecea, F.J., et al. (2010) L3-L4 Dislocation without Neurological Lesions. Bulletin of the NYU Hospital for Joint Diseases, 68, 60-64.

[14] Solera, J.M.R., de la Haba, A.M.C., León, M.S.H. and Parra, E.G. (2015) Fracture Dislocation of the Upper Thoracic Spine without Neurologic Associated Injury: Two Cases Report. Trauma Cases and Reviews, 1, 22. https://doi.org/10.23937/2469-5777/1510022

[15] Sugiura, K., Sakai, T., Adachi, K., Inoue, K., Endo, S., Tamaki, Y., et al. (2016) Complete Fracture-Dislocation of the Thoracolumbar Spine with No Critical Neurological Deficit: A Case Report. The Journal of Medical Investigation, 63, 122-126. https://doi.org/10.2152/jmi.63.122

[16] Zeng, J., Gong, Q., Liu, H., Rong, X. and Ding, C. (2018) Complete Fracture Dislocation of the Thoracolumbar Spine without Neurological Deficit: A Case Report and Review of the Literature. Medicines, 97, e0050. https://doi.org/10.1097/MD.0000000000010050

[17] Evans, L.J. (2012) Images in Clinical Medicine. Thoracolumbar Fracture with Preservation of Neurologic Function. The New England Journal of Medicine, 367, 19-39. https://doi.org/10.1056/NEJMicm1101495

[18] Enishi, T., Katoh, S. and Sogo, T. (2014) Surgical Treatment for Significant Fracture-Dislocation of the Thoracic or Lumbar Spine without Neurologic Deficit: A Case Series. Journal of Orthopaedic Case Reports, 4, 43-45.

[19] Rahimizadeh, A., Asgari, N. and Rahimizadeh, A. (2017) Complete Thoracolumbar Fracture-Dislocation with Intact Neurologic Function: Explanation of a Novel Cord Saving Mechanism. The Journal of Spinal Cord Medicine, 41, 367-376.

[20] Zhang, S. and Yan, T.B. (2017) Severe Fracture Dislocation of the Thoracic Spine without Any Neurological Deficit. World Journal of Surgical Oncology, 15, Article No. 3.

[21] Zeng, J.F., Gong, Q., Liu, H., Rong, X. and Ding, C. (2018) Complete Fracture-Dislocation of the Thoracolumbar Spine without Neurological Deficit, a Case Report and Review of the Literature. Medicine (Baltimore), 97, e0050. https://doi.org/10.1097/MD.0000000000010050

[22] Kumar, S., Kumar, P., Patralekh, M.K., Srinivasan, R., Agarwal, A. and Boruah, T. (2020) Fracture-Dislocation of the Thoracolumbar Spine without Neurological Deficit: A Report of Two Cases and Literature Review. Spinal Cord Series and Cases, 6, 67. https://doi.org/10.1038/s41394-020-0315-4

[23] Xu, F., Tian, Z., Fu, C., Yao, L., Yan, M., Zou, C., Liu, Y. and Wang, Y. (2020) Mid-Lumbar Traumatic Spondyloptosis without Neurological Deficit: A Case Report and Literature Review. Medicine, 99, e19578. https://doi.org/10.1097/MD.0000000000019578

[24] Zarate-Kalfopoulos, B., Romero Vargas, S., Alcantara-Canseco, C., Rosales-Olivarez, L.M., Alpizar-Aguirre, A., et al. (2012) Traumatic Posterior L4-L5 Fracture Dislocation of the Lumbar Spine: A Case Report. Global Spine Journal, 2, 235-238. https://doi.org/10.1055/s-0032-1329889 
[25] Abdel, F.H. and Rizik, A.H. (1990) Complete Fracture-Dislocation of the Lower Lumbar Spine with Spontaneous Neurologic Decompression. Clinical Orthopaedics and Related Research, 251, 140-143. https://doi.org/10.1097/00003086-199002000-00022

[26] Enishi, T., Katoh, S. and Sogo, T. (2014) Surgical Treatment for Significant Fracture-Dislocation of the Thoracic or Lumbar Spine without Neurologic Deficit: A Case Series. Journal of Orthopaedic Case Reports, 4, 43-45.

[27] Caldera, G. and Cahueque, M. (2016) Recovery after Fracture Dislocation of L3/L4 ASIA B: Case Report. Trauma Case Reports, 2, 9-15.

https://doi.org/10.1016/j.tcr.2016.03.003

[28] Wood, K.B., Li, W., Lebl, D.R., et al. (2014) Management of Thoracolumbar Spine Fractures. The Spine Journal, 14, 145-164. https://doi.org/10.1016/j.spinee.2012.10.041

[29] Wang, F. and Zhu, Y. (2013) Treatment of Complete Fracture-Dislocation of Thoracolumbar Spine. Journal of Spinal Disorders \& Techniques, 26, 421-426. https://doi.org/10.1097/BSD.0b013e31824e1223

[30] Guzel, A., Belen, D., Tatli, M., Simsek, S. and Guzel, E. (2006) Complete L1-L2 Lateral Dislocation without Fracture and Neurologic Deficit in a Child. Pediatric Neurosurgery, 42, 183-186. https://doi.org/10.1159/000091865

[31] Alobaid, A., Arlet, V., Ouellet, J. and Reindl, R. (2006) Surgical Technique. Technical Notes on Reduction of Thoracic Spine Fracture Dislocation. Canadian Journal of Surgery, 49, 131-134.

[32] Wang, X.-B., Yang, M., Li, J., Xiong, G.-Z., Lu, C. and Lü, G.-H. (2014) Thoracolumbar Fracture Dislocations Treated by Posterior Reduction, Interbody Fusion and Segmental Instrumentation. Indian Journal of Orthopaedics, 48, 568-573.

https://doi.org/10.4103/0019-5413.144219

[33] Xia, Q., Xu, B.S., Zhang, J.D., Miao, J., Li, J.G., Zhang, X.L., et al. (2009) Simultaneous Combined Anterior and Posterior Surgery for Severe Thoracolumbar Fracture Dislocations. Orthopaedic Surgery, 1, 28-33. https://doi.org/10.1111/j.1757-7861.2008.00006.x

[34] Hamzaoglu, A., Ozturk, C., Aydogan, M., et al. (2008) Posterior Only Pedicle Screw Instrumentation with Intraoperative Halo-Femoral Traction in the Surgical Treatment of Severe Scoliosis (>100 Degrees). Spine, 33, 979-383. https://doi.org/10.1097/BRS.0b013e31816c8b17

[35] Uriarte, E., Elguezabal, B. and Tovio, R. (1987) Fracture-Dislocation of the Thoracic Spine without Neurologic Lesion. Clinical Orthopaedics and Related Research, 217, 261-265. https://doi.org/10.1097/00003086-198704000-00028

[36] Hutchinson, M.R. and Dall, B.E. (1993) Fracture-Dislocation of the Thoracic and Lumbar Spine: Advantages of Halo-Bifemoral Traction. Journal of Spinal Disorders, 6, 482-488. https://doi.org/10.1097/00002517-199306060-00003

[37] Kumar, S., Patralekh, M.K., Boruah, T., Kareem, S.A., Kumar, A. and Kumar, R. (2020) Thoracolumbar Fracture Dislocation (AO Type C Injury): A Systematic Review of Surgical Reduction Techniques. Journal of Clinical Orthopaedics and Trauma, 11, 730-741. https://doi.org/10.1016/j.jcot.2019.09.016

[38] Kanna, R.M., Raja, D.C., Shetty, A.P. and Rajasekaran, S. (2021) Thoracolumbar Fracture Dislocations without Spinal Cord Injury: Classification and Principles of Management. Global Spine Journal, 11, 63-70.

https://doi.org/10.1177/2192568219890568 